УДК 631.3

(СВ.В. Сацюк, к.т.н., О.I. Антонюк

Луцький національний технічний університет

І.В. Деміх, Н.Г. Остапук

Любешівський технічний коледж Луцького національного технічного університету

\title{
ДОСЛІДЖЕННЯ ПРОЦЕСУ ВНЕСЕННЯ ВЕРХОВОГО ТОРФУ ПІД ПОСАДКУ ЛОХИНИ
}

У статті описано технологію внесення верхового торфу під посадку лохини. Запропонована конструкиія машини для локального внесення верхового торфу. Наведено результати дослідження впливу геометричних параметрів инкового дозатора та вологості верхового торфу на коефіцієнт варіації маси дози матеріалу, виданої за одиницю часу.

ЛОХИНА, ВЕРХОВИЙ ТОРФ, ШНЕК, ВНЕСЕННЯ,
ДОЗУВАННЯ, РІВНЯННЯ РЕГРЕСІЇ

Постановка проблеми. Лохина, в країнах колишнього СНД більше відома виключно як дикоростучий чагарник, увійшла в культуру відносно недавно і для багатьох садівників все ще залишається "темною конячкою». «Показна невибагливість», що дозволяє цій рослині виживати на сірих болотах, в суворій тундрі і в посушливому верхньому поясі гір, на садових ділянках часто обертається примхливістю, відмовою від плодоношення і слабким зростанням.

Розумний підхід до іï агротехніці гарантує і нормальний ріст, і стабільне плодоношення. Адже в Америці саме лохина вважається однією 3 найперспективніших культур для промислового вирощування на абсолютно непридатних для сільського господарства ділянках, а в Канаді вона в популярності нерідко змагається навіть з кращими сортами смородини.

Спонтанна посадка лохини - без попереднього вивчення іiі особливостей і підготовки гранту - в більшості випадків рано чи пізно призводить до загибелі рослини.

Грунт для лохини має бути добре дренований і мати кислу реакцію, у зв'язку з чим посадкові ями рекомендується заповнювати верховим торфом $з$ додаванням тирси, хвойного опаду або землі 3 соснового лісу (не більш третини від загальної маси субстрату). Торф під посадку лохини необхідно брати верховий (рудуватий), кислотність якого найбільш оптимальна (pH не вище 4,0), так як у 
торфу перехідного болота і низинного торфу вона становить 6,0 одиниць, що для лохини вже неприпустимо. Вносити добрива в посадкову яму не обов'язково - для успішного приживання саджанців поживність грунту відіграє значно меншу роль, ніж іiі кислотність. [1],[2].

Аналіз останніх досліджень i публікацій. Відомі дослідження процесу локального внесення органічних добрив стосуються внесення сапропелю під посадку картоплі [3]. Локальне внесення верхового торфу під посадку лохини не досліджувалось.

Мета дослідження. Розробити конструкцію машини для локального внесення верхового торфу. Провести лабораторновиробничі випробування шнекового дозатора 3 метою встановлення впливу факторів на коефіцієнт варіації маси дози верхового торфу, виданої за одиницю часу.

Результати дослідження. Машина для локального внесення верхового торфу під посадку лохини (рис.1), являє собою складну конструкцію та спроектована на базі розкидача органічних добрив.
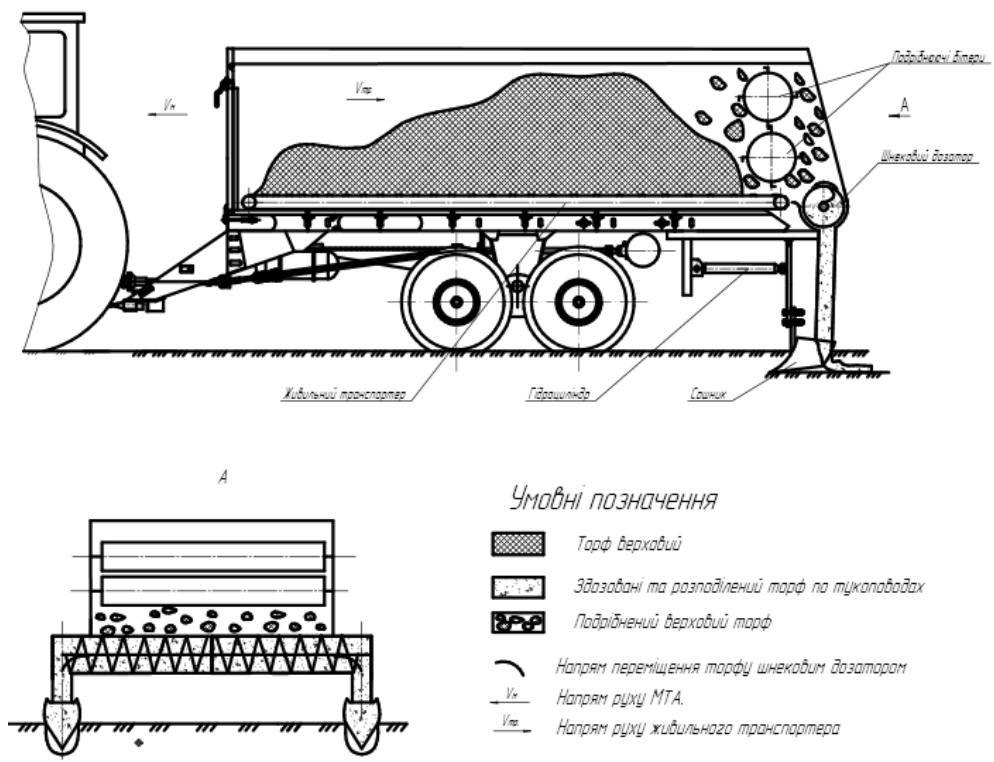

Умовні позначення

Topd bepxobui

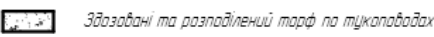

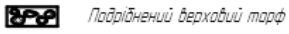

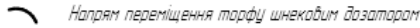

$+V_{*}$ Hangam oLxy MTA.

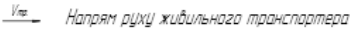

Рис.1 - Функціональна схема машини для локального внесення верхового торфу під посадку лохини 
Усі робочі механізми машини мають привід від валу відбору потужності трактора, 3 яким агрегатується машина. Крутний момент від валу відбору потужності до машини для локального внесення торфу передається за допомогою телескопічного карданного вала.

Верховий торф завантажується у кузов машини для локального за допомогою фронтального навантажувача. На початку загінки механізатор за допомогою гідроциліндра опускає сошники у грунт на глибину внесення торфу. Верховий торф за допомогою живильного транспортера подається до подрібнювальних бітерів.

Подрібнювальні бітери змонтовані в коробці і прикріплені до рами. Вони - це вали з шліцевими втулками, з ввареними по торцях підвалами для кріплення на них підшипників і опори для обертання, тобто ланцюгів. Бітери приводяться в рух від конічного редуктора, який, в свою чергу, працює від карданної передачі від ВВП трактора. На вихідному кінці (збоку) бітерів на кінці розміщена циліндрична шестерня, яка входить в зчеплення з шестернею, що змонтована на тихохідному валу конічного редуктора. Подрібнений та розрихлений торф подається на шнековий дозатор.

Шнековий дозатор представляє собою двох секційний шнековий живильник який змонтований на одному валу. Кожна секція проводить живлення верхового торфу під рядок посадки лохини. Секції розділенні між собою за допомогою перегородок . У жолобі шнека із кроком який відповідає ширині посадки лохини змонтовані вивантажувальні вікна. Ширина забірної частини для живильників однакова і становить половину ширини кузова машини.

Норма внесення верхового торфу регулюється швидкістю руху живильного транспортера.

Для дослідження процесу дозування верхового торфу використовували дослідну установку шнекового дозатора (рис.2). Установка складається із опорної рами 1, на якій закріплено гладкий нерухомий кожух 2, завантажувальна горловина 3 та підшипникові опори 4. У підшипникових опорах, встановлений шнековий вал 5. На рамі змонтований привід шнекового вала, який складається з електродвигуна трьохфазного струму 6, клинопасової передачі 7 та натяжного механізму 8 . факторів:

Дослідження проводилось із варіюванням наступних

- вологісті торфу W, \% ;

- висоти шару матеріалу у бункері h, м

- $\quad$ кута нахилу осі шнека до горизонту $\beta$. 


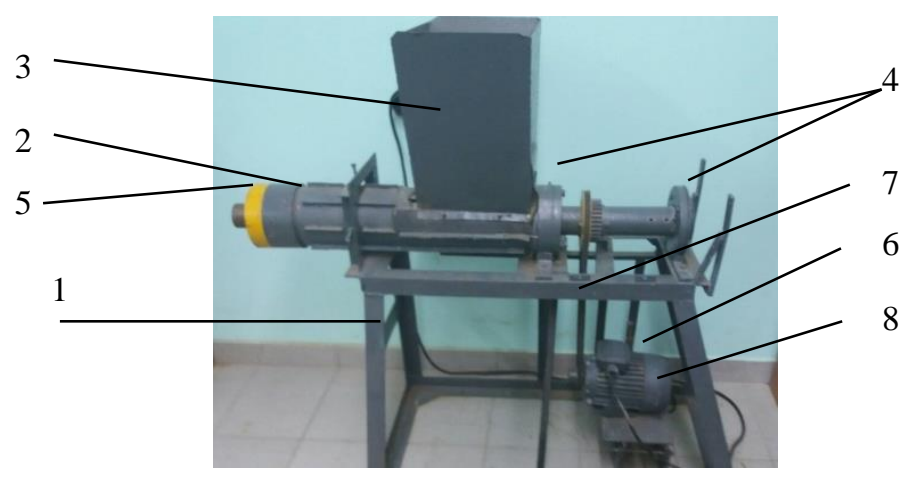

Рис. 2 - Дослідна установка шнекового дозатора

Для дослідження процесу дозування верхового торфу машиною для локального внесення його під посадку лохини, застосовували математичний метод планування експерименту із використанням симетричного не композиційного плану реалізації експерименту Бокса-Бенкіна другого порядку [4]. Метою експерименту було визначення коефіцієнту варіації маси дози матеріалу, виданої за одиницю часу при варіюванні таких факторів як вологість торфу, висота торфу у бункері, та кут нахилу осі шнека до горизонту.

Обробка даних результатів трьохфакторного експерименту згідно з трирівневим планом другого порядку на ЕОМ, дозволила отримати рівняння регресії, функцією відгуку якого $є$ коефіцієнт варіації маси дози матеріалу, виданої за одиницю часу :

$$
y=14,12-0,789 \cdot x_{3}+1,047 \cdot x_{1}^{2}+1,181 \cdot x_{2}^{2}-1,286 x_{2}^{3}
$$

де $\mathrm{x}_{1}$ - кодоване значення кутової вологості верхового торфу;

$\mathrm{x}_{2}$ - кодоване значення висоти торфу у бункері;

$\mathrm{x}_{2}$ - кодоване значення кута встановлення осі шнека до горизонту.

Перевірку адекватності отриманого рівняння регресії (1) проводили за допомогою критерію Фішера $\mathrm{F}_{\phi}$, а оцінка значущості коефіцієнтів регресії проводилась за допомогою критерію Стьюдента. 
Підставивши фактори у рівняння (1) отримали рівняння регресії у натуральному вигляді:

$$
\begin{gathered}
\mathrm{y}(\mathrm{W}, \mathrm{h}, \beta)=101,9-3.769 \mathrm{~W}-15.15 \mathrm{~h}-0.05 \beta+0,042 \mathrm{~W}^{2}+ \\
+18.89 \mathrm{~h}^{2}-0.006 \beta^{2}
\end{gathered}
$$

За отриманим рівнянням регресії (2), були побудовані поверхні відгуку (рис. 3.) для відслідковування динаміки зміни коефіцієнту варіації маси дози верхового торфу, виданої за одиницю часу.

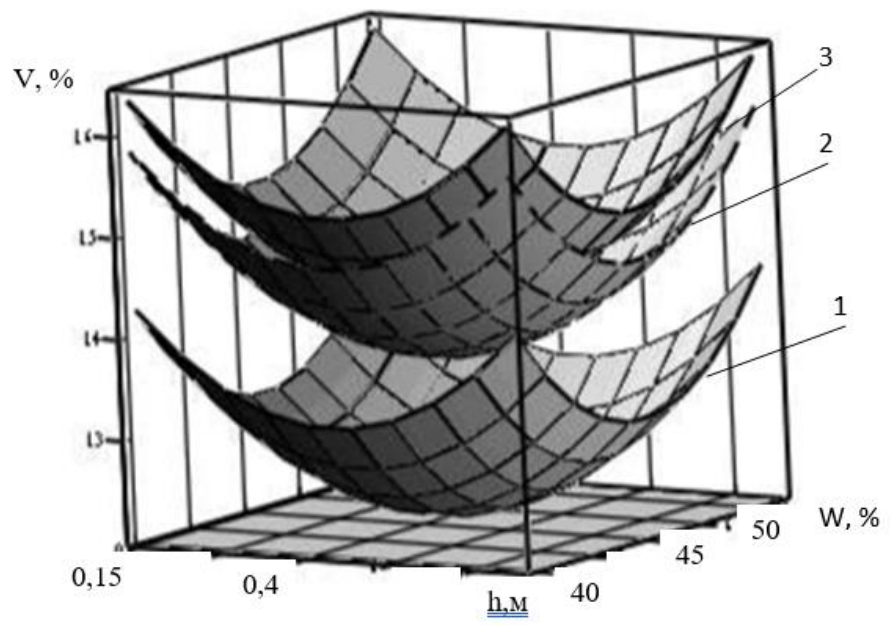

Рис. 3. - залежність коефіцієнту варіації маси дози матеріалу, виданої за одиницю часу при зміні таких факторів як вологість торфу w, висота торфу у бункері $\mathrm{h}$ при кут нахилу осі шнека до горизонту: $1-\beta=0^{0} ; 2-\beta=15^{0} ; 3-\beta=-15^{0}$

Висновки. Аналізуючи отримані поверхні відгуку, можна зробити висновок, що на зміну коефіцієнту варіації маси дози верхового торфу, виданої за одиницю часу шнековим дозатором впливають усі досліджувані фактори. Точність дозування зростає при збільшені вологості торфу в межах $\mathrm{W}=40 \ldots 45 \%$. Найвища точність дозування досягається при куті нахилу осі шнека до горизонту $\beta=0^{0}$. 


\section{Література}

1. Лохина - посадка й догляд, вирощування - Режим доступу: https://floristics.info/ua/statti/sad/2352-lokhina-posadka-jdoglyad-viroshchuvannya.html.

2. Лохина: вирощування та догляд. - Режим доступу: http://kvitkainfo.com/sad-gorod/lohina-doglyad.html.

3. Обгрунтування процесу та параметрів машини для локального внесення сапропелевих добрив [Текст] : автореф. дис. ... канд. техн. наук : 05.05.11 / Поліщук Микола Миколайович ; Львів. нац. аграр. ун-т. - Львів, 2014. - 25 с.

4. Новик Ф.С., Арсов Я.Б. Оптимизация процессов технологи металлов методами планирования экпериментов. - M.: Машиностроение, София: Техника, 1980. - 304. 